\title{
Macrocephaly, epilepsy and intracranial cysts: an image to remember
}

\author{
Mounika Endrakanti, ${ }^{1}$ Vijay Gonda, ${ }^{1}$ Arushi Gahlot Saini, ${ }^{2}$ Manphool Singhal ${ }^{3}$
}

'Department of Pediatrics, Postgraduate Institute of Medical Education and Research, Chandigarh, India ${ }^{2}$ Pediatric Neurology Unit, Department of Pediatrics, Postgraduate Institute of Medical Education and Research, Chandigarh, India ${ }^{3}$ Department of Radiodiagnosis, Postgraduate Institute of Medical Education and Research, Chandigarh, India

\section{Correspondence to} Dr Arushi Gahlot Saini, doctorarushigahlot@gmail.com

Accepted 11 April 2018
Check for updates

To cite: Endrakanti $\mathrm{M}$, Gonda V, Saini AG, et al. BMJ Case Rep Published Online First: [please include Day Month Year]. doi:10.1136/ bcr-2018-225173

\section{DESCRIPTION}

An 11-year-old, developmentally normal girl presented with recurrent seizures for the past 2 years. She was also noted to have progressively increasing head size since early infancy. She was born to non-consanguineous parents from the Aggarwal community in India and had a 7-year-old younger sister with similar problems. There was no associated history of vision impairment, tone abnormalities, cognitive or behavioural problems, extrapyramidal movements or gait changes. Examination showed head circumference of $58 \mathrm{~cm}$ ( $>3 \mathrm{z}$-scores), a single café-au-lait macule and normal bilateral fundi. The rest of the systemic examination was unremarkable. Parental head circumference was normal. She was evaluated for familial macrocephaly with epilepsy. MRI brain showed diffuse involvement of the subcortical and periventricular white matter with sparing of corpus callosum and formation of subcortical cysts (figure 1A-D). Electroencephalogram showed intermittent spike-slow waves from left temporal and right centroparietal areas and bilateral frontal intermittent rhythmic delta activity. Targeted genetic sequencing revealed compound heterozygous mutations c.135insC and p.Q315R in exon 2 of MLC1 gene on chromosome 22 in both the sisters. Mother carried only c.135insC and father carried only p.Q315R

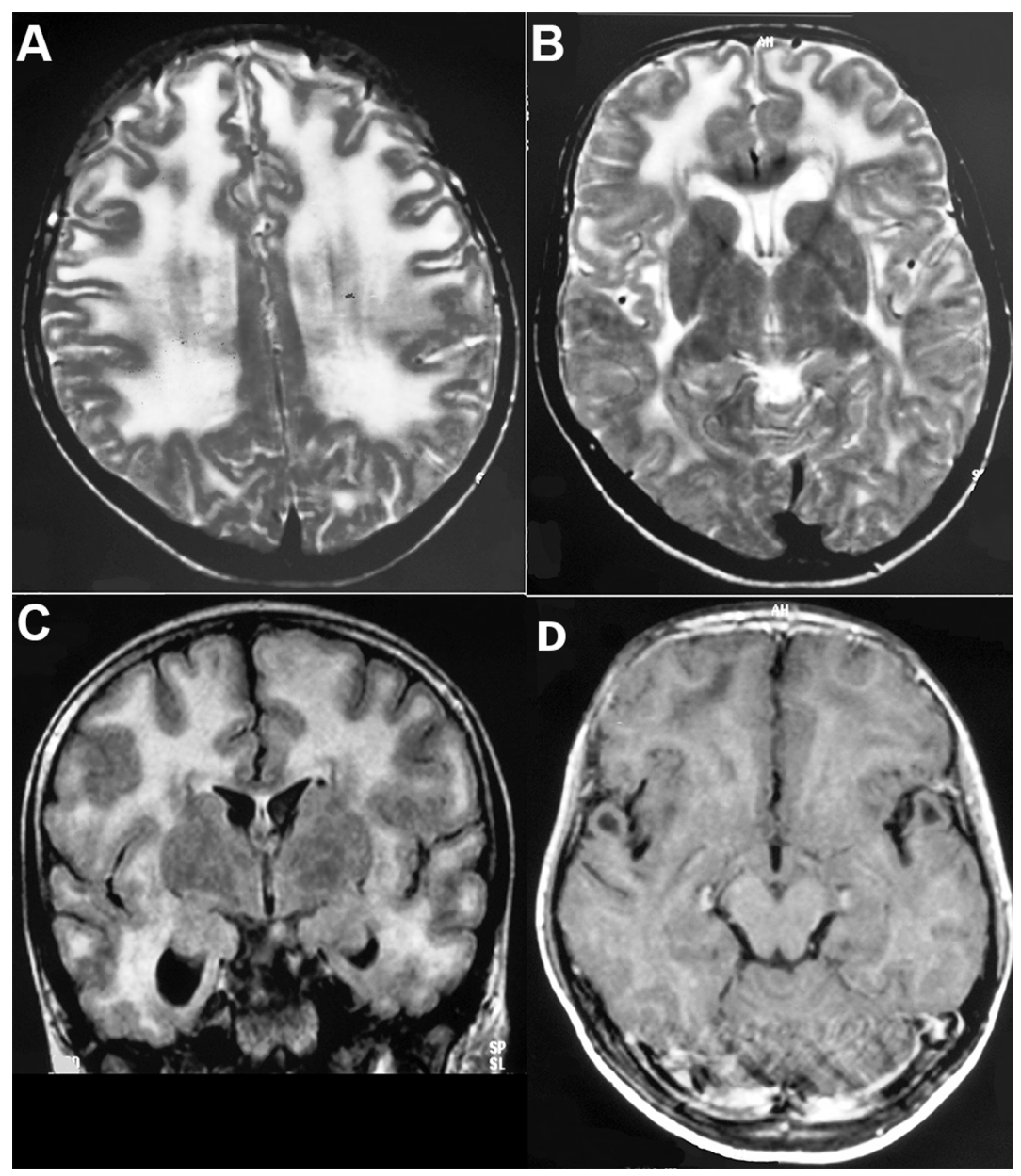

Figure $1 \mathrm{MRI}$ of the brain (A-B) axial T2-weighted sections showing diffuse hyperintensities involving the subcortical white matter, bilateral centrum semiovale, external capsule and periventricular white matter with sparing of corpus callosum, bilateral cortex, thalami, internal capsule and basal ganglia (C) coronal fluid attenuated inversion recovery (FLAIR) section showing similar periventricular and subcortical white matter hyperintensities with prominent bilateral temporal cysts (D) axial T1-weighted section showing bilateral frontal white matter hypointensities and temporal cysts. Overall, the radiological picture is consistent with megalencephalic leukoencephalopathy with subcortical cysts. 


\section{Learning points}

- Megalencephalic leukoencephalopathy is a rare autosomal recessive disease presenting with progressive macrocephaly since infancy.

- Subcortical cysts in a child with large head clinch the diagnosis.

- Ethnic predisposition has been observed in the Aggarwals and their related communities in India.

mutations. The mutation p.Q315R was novel and interpreted as damaging by software analysis. The patient was initiated on oral oxcarbazepine. Currently, she is 18 years old, studying in 12th standard and is asymptomatic.

Megalencephalic leukoencephalopathy with subcortical cysts (MLC) or Van der Knaap disease is a rare autosomal-recessive leukodystrophy characterised by infantile-onset macrocephaly, mild-moderate delay in motor milestones and seizures. Lateonset motor deterioration with development of ataxia, spasticity, extrapyramidal symptoms and cognitive impairment is often observed with subsequent development of cerebral atrophy and increasing subcortical cysts. ${ }^{1}$ From India, the condition was first described in 18 patients by Singhal et al. ${ }^{2}$ An ethnic predisposition has been observed in the Indian Agarwal community, Libyan Jews and Turks. ${ }^{2}$

Common differential diagnoses include Alexander disease, Canavan disease, $\mathrm{GM}_{1}$ and infantile-onset $\mathrm{GM}_{2}$ gangliosidosis, glutaric aciduria type 1 and, rarely, L-2-hydroxyglutaric aciduria and merosin-deficient congenital muscular dystrophy. MRI is diagnostic and shows bilaterally symmetrical, supratentorial white matter hyperintensities and temporal subcortical cysts with sparing of central grey matter structures and a decrease in $\mathrm{N}$-acetylaspartate/creatinine peak and choline/creatinine ratio. ${ }^{1}$ MLC has a remarkable slowly progressive course which differentiates it from other disorders with macrocephaly and early-onset progressive leukoencephalopathies.

Contributors ME, VG: clinical care and draft of manuscript. AGS: clinical care and review and approval of final draft of manuscript. MS: radiological analysis and approval of the final draft of the manuscript.

Funding This research received no specific grant from any funding agency in the public, commercial or not-for-profit sectors.

Competing interests None declared.

Patient consent Parental/guardian consent obtained.

Provenance and peer review Not commissioned; externally peer reviewed.

(c) BMJ Publishing Group Ltd (unless otherwise stated in the text of the article) 2018. All rights reserved. No commercial use is permitted unless otherwise expressly granted.

\section{REFERENCES}

1 Schiffmann R, van der Knaap MS. Invited article: an MRI-based approach to the diagnosis of white matter disorders. Neurology 2009;72:750-9.

2 Singhal BS, Gursahani RD, Udani VP, et al. Megalencephalic leukodystrophy in an Asian Indian ethnic group. Pediatr Neurol 1996;14:291-6.

3 Ben-Zeev B, Gross V, Kushnir T, et al. Vacuolating megalencephalic leukoencephalopathy in 12 Israeli patients. J Child Neurol 2001;16:93-9.

Copyright 2018 BMJ Publishing Group. All rights reserved. For permission to reuse any of this content visit http://group.bmi.com/group/rights-licensing/permissions.

BMJ Case Report Fellows may re-use this article for personal use and teaching without any further permission.

Become a Fellow of BMJ Case Reports today and you can:

- Submit as many cases as you like

- Enjoy fast sympathetic peer review and rapid publication of accepted articles

- Access all the published articles

- Re-use any of the published material for personal use and teaching without further permission

For information on Institutional Fellowships contact consortiasales@bmjgroup.com

Visit casereports.bmj.com for more articles like this and to become a Fellow 